\title{
Growth, nutrition and efficiency in the transport, uptake and use of nutrients in african mahogany ${ }^{1}$
}

\author{
Crescimento, nutrição e eficiência no transporte, absorção e uso de nutrientes no \\ mogno africano
}

\author{
Aline das Graças Souza ${ }^{2 *}$, Oscar José Smiderle ${ }^{3}$, Edvan Alves Chagas ${ }^{3}$, Márcia Souza Alves ${ }^{4}$ and Paulo Renato \\ de Oliveira Fagundes ${ }^{4}$
}

\begin{abstract}
African mahogany is a species preferred by many entrepreneurs as an investment in the forestry sector. However, there are few studies or research on the species, especially in Brazil. The aim of this work was to study the efficiency of nutrient uptake, accumulation, distribution and use in Khaya ivorensis and Khaya senegalensis, in addition to aspects of growth variables and of dry matter partitioning as a function of mineral fertilisation. Morphological, physiological and nutritional parameters were determined in the African mahogany plants 140 days after transplanting (DAT). The greatest zinc $(\mathrm{Zn})$ content was detected in the shoots of both the Khaya ivorensis and Khaya senegalensis plants, accounting for more than $50 \%$ of the accumulated total of the plants with added nutrient solution. Maintaining the plants of Khaya senegalensis and Khaya ivorensis with the use of nutrient solution provides the best conditions for nutrient use, and allows plants with excellent morphological and nutritional characteristics to be ready for the field within five months after transplanting in a shaded nursery. The most efficient uptake, transport and use of macro and micronutrients is found in the species Khaya senegalensis with the addition of nutrient solution.
\end{abstract}

Key words: Khaya senegalensis. Khaya ivorensis. Seedling production. Nutrient partitioning. Mineral nutrition.

RESUMO - O mogno africano é uma espécie que vêm se destacando na preferência dos empresários como opção no investimento florestal. Porém, estudos e pesquisas sobre a espécie, principalmente no Brasil, são escassos. O objetivo neste trabalho foi estudar a eficiência de absorção, acúmulo, distribuição e uso de nutrientes em Khaya ivorensis e Khaya senegalensis, além de aspectos relacionados as variáveis de crescimento e de partição de matéria seca em função da adubação mineral. Parâmetros morfológicos, fisiológicos e nutricionais foram determinados nas plantas de mogno africano aos 140 dias após o transplantio (DAT). O maior teor de zinco (Zn) foi detectado nas brotações das plantas de Khaya ivorensis e Khaya senegalensis, representando mais de 50\% do total acumulado das plantas com adição de solução nutritiva. A manutenção das plantas de Khaya senegalensis e Khaya ivorensis com o uso de solução nutritiva fornece as melhores condições para o uso de nutrientes, e permite que plantas com excelentes características morfológicas e nutricionais estejam prontas para o campo dentro de cinco meses após o transplantio em viveiro sombreado. A absorção, transporte e uso mais eficientes de macro e micronutrientes são encontrados na espécie Khaya senegalensis com a adição de solução nutritiva.

Palavras-chave: Khaya senegalensis. Khaya ivorensis. Produção de mudas. Particionamento de nutrientes. Nutrição mineral.

\footnotetext{
DOI: $10.5935 / 1806-6690.20200024$

*Author for correspondence

Received for publication in 29/04/2019; approved in 01/12/2019

${ }^{1}$ Trabalho extraído da Tese do quinto autor a ser apresentada no Programa de Pós-Graduação em Agronomia, Universidade Federal de Roraima/UFRR ${ }^{2}$ Programa de Pós-Graduação em Agronomia, Departamento de Ciências Vegetais e Ambientais, Universidade Federal da Paraíba/UFPB, Campus II Areia-PB, Brasil, alineufla@ hotmail.com (ORCID ID 0000-0001-8158-5933)

${ }^{3}$ Empresa Brasileira de Pesquisa Agropecuária - Embrapa Roraima, Boa Vista-RR, Brasil, oscar.smiderle@embrapa.br (ORCID ID 0000-0001-66921329), edvan.chagas@embrapa.br (ORCID ID 0000-0001-8604-7819) - Bolsistas de Produtividade em Pesquisa do CNPq

${ }^{4}$ Programa de Pós-Graduação em Agronomia, Universidade Federal de Roraima, Boa Vista-RR, Brasil, marciasouza@ hotmail.com (ORCID ID 0000-0002-0623-601X), pro.fagundes@yahoo.com.br (ORCID ID 0000-0001-8348-6269)
} 


\section{INTRODUCTION}

The genus Khaya belongs to the family Meliaceae. Originating in Africa and Latin America, the family comprises 51 genera covering 1.400 species, $60 \%$ of which are part of the forest economy of various countries. The genus Khaya spp. is known by many authors as African mahogany (SMIDERLE et al., 2016).

The wood is of fine-quality, with great economic potential on the domestic and international markets, and can be used in the furniture and naval industries, in civil construction, and for panels and laminates, among other uses.

Khaya ivorensis has wood of a red to pale brown colour, a mean basic density of $0.47 \mathrm{~g}$ to $0.58 \mathrm{~g} . \mathrm{cm}^{-3}$ and good workability (CENTRE FOR AGRICULTURE AND BIOSCIENCES INTERNATIONAL, 2013). Wood of the genus Khaya is highly valued on the international market: one cubic metre of native logs can fetch approximately USD 1000, according to import and export records for different wood products of the genus Khaya published by the International Tropical Timber Organization International Tropical Timber Organization (2011).

Mahogany is still one of the most exploited species in the country, and as such, is threatened with extinction, as renewal of the native tree is not in proportion to its exploitation. The need to invest in developing research into the production of mahogany seedlings for the purposes of reforestation is essential. The success of forestation and reforestation projects depends on various factors, but the quality of seedlings placed in the field is extremely important. This requires knowledge of species in various areas of the forestry sector. Most single or intercropped species fail due to problems related to the growing conditions, including seedling quality.

In Brazil, the species was initially introduced in the north of the country through seeds donated to the researcher Ítalo Falesi in 1976, but it was only in 1989 that trees from these seeds began to reproduce, allowing the species to spread around the country. the State of Roraima has extensive arable land, which is currently under-exploited due to lack of investment in research, trained personnel, infrastructure and technical knowledge, especially regarding the nutritional requirements, morphological response and seedling growth of these species in production systems in protected environments using substrates and mineral fertiliser.

Fertilising plants with nutrient solution has increasingly been used in the nutritional management of forest species, aiming to optimise the use of inputs and plant growth under different cropping systems with minimal waste to the environment (PRADEEPKUMAR et al., 2017). Nutrient solutions also have a wide application in studies of plant physiology, with a view to studying and correlating the presence and concentration of mineral nutrients with the processes that coordinate plant growth (BALDI et al., 2014).

According to Souza et al. (2017), adding the complete nutrient solution formulated by Souza et al. (2011) to substrates is a promising technique for the initial formation of forest plants in the greenhouse. Another strategy for identifying nutritional requirements is to determine the ideal concentration for promoting the best uptake, distribution and use of nutrients, and their effects on growth variables (BALDI et al., 2014; ELSADR; SHERIF, 2016), and of dry matter partitioning on the mineral composition of plant roots, stem and leaves (ELSADR; SHERIF, 2016).

Among the most-used organs to estimate the nutritional status of plants, the leaf is the most important, as it is the seat of metabolism, responsible for the production of photoassimilates (SOUZA et al., 2019), reflecting nutritional changes in its composition, and expressing the symptomatic effects of nutrient status in its colouration (MERIÑO-GERGICHEVICH et al., 2017).

In addition to the organic macronutrients carbon, hydrogen and oxygen, which represent the largest part of plant dry weight (SOMMER et al., 2016), it should be remembered that the other mineral elements, although required in smaller quantities, are a key point in the performance of major metabolic cell functions and plant growth (MILOŠEVIC; MILOŠEVIC; GLISIC, 2013).

The aim of this study, therefore, was to evaluate the efficiency of nutrient uptake, accumulation, distribution and use in Khaya ivorensis and Khaya senegalensis, in addition to aspects of growth variables and of dry matter partitioning as a function of mineral fertilisation.

\section{MATERIAL AND METHODS}

The research was conducted at the seedling nursery of Embrapa Roraima, located in the Industrial District, at Km 8 of the BR 174 highway, at $02^{\circ} 45^{\prime} 28^{\prime \prime}$ $\mathrm{N}$ and $60^{\circ} 43^{\prime} 54^{\prime \prime} \mathrm{W}$, and an altitude of $90 \mathrm{~m}$. The city of Boa Vista is in the Tropical Climate Zone (SMIDERLE et al., 2018). According to Köppen, the climate in the region is type Aw (tropical rainy with a short dry season) with a mean annual rainfall of between 1700-2000 mm (SMIDERLE et al., 2018). The mean annual temperature is $25.5^{\circ} \mathrm{C}$.

The species Khaya ivorensis and Khaya senegalensis were used as plant material, with seedlings 
grown from seeds obtained from parent plants of the Brazilian Forestry Institute (Instituto Brasileiro de Florestas - IBF).

The seeds were sown in a seedbed that contained washed medium sand as substrate for the germination and initial development of the seedlings. The seedlings were placed in 14-L polypropylene pots containing a thin layer of approximately $5 \mathrm{~cm}$ of pebbles to improve drainage and OrganoAmazon ${ }^{\circledR}$ ORG substrate (Table 1), a commercial organic compound (100\% natural, regional organic fertiliser, consisting of cattle, horse, chicken and sheep manure, aged and charred rice straw, peat, bagasse, grass clippings, galls and foliage).

The plants were kept on benches in a nursery under $50 \%$ shade, with irrigation by programmed sprinkler every five hours during the day, each irrigation lasting five minutes. The plants were irrigated twice weekly with $200 \mathrm{~mL}$ of the nutrient solution proposed by Souza et al. (2018), after the final irrigation of the day to avoid nutrient leaching (Table 2).

The experimental design was a $2 \times 2$ factorial scheme (with and without the addition of nutrient solution, and two species of African mahogany Khaya ivorensis and Khaya senegalensis).

At 140 days after transplanting (DAT), the height (using a millimetre rule) and stem diameter $(10 \mathrm{~cm}$ above the substrate with the aid of a digital calliper) were determined. Root and shoot dry matter were also determined, with the aim of evaluating assimilate partitioning. The shoots and roots were separated and packed in paper bags, remaining in a drying oven at $70^{\circ} \mathrm{C}$ for 72 hours. After drying, the samples were weighed on a $0.01 \mathrm{~g}$ precision balance to determine shoot dry weight (SDW), root-system dry weight (RDW), and from the sum of these two values, the dry weight of the plant (TDW). The formula proposed by Dickson, Lead and Osmer (1960) to define the Dickson Quality Index (DQI) was used to measure plant quality.

The roots and shoots were then ground in a Wiley mill with a 20-mesh screen, and the macro- and micronutrient concentrations were analysed as per Malavolta, Vitti and Oliveira (1997). The content of each nutrient was calculated by multiplying the dry weight of each part of the plant by the concentration of each nutrient (BATAGLIA et al., 1983). The following indices were also calculated: (a) uptake efficiency $=$ (total nutrient content of the plant)/(root-system dry weight), as per Swiader, Chyan and Freiji (1994); (b) transport efficiency $=[$ (nutrient content of the shoots $) /($ total nutrient content of the plant)] x 100, as per Li, Mckeand and Allen (1991); (c) use efficiency $=(\text { total dry matter produced })^{2} /($ total nutrient content of the plant), in macronutrients $\left(\mathrm{mg} \mathrm{plant}^{-1}\right)$ and micronutrients $\left(\mu \mathrm{g}\right.$ plant $\left.^{-1}\right)$ respectively, as per Siddiqi and Glass (1981). Analysis of variance and comparison of mean

Table 1 - Chemical composition, micronutrients and granulometry of the substrate (OrganoAmazon ${ }^{\circledR}$ ) used in growing Khaya ivorensis and Khaya senegalensis

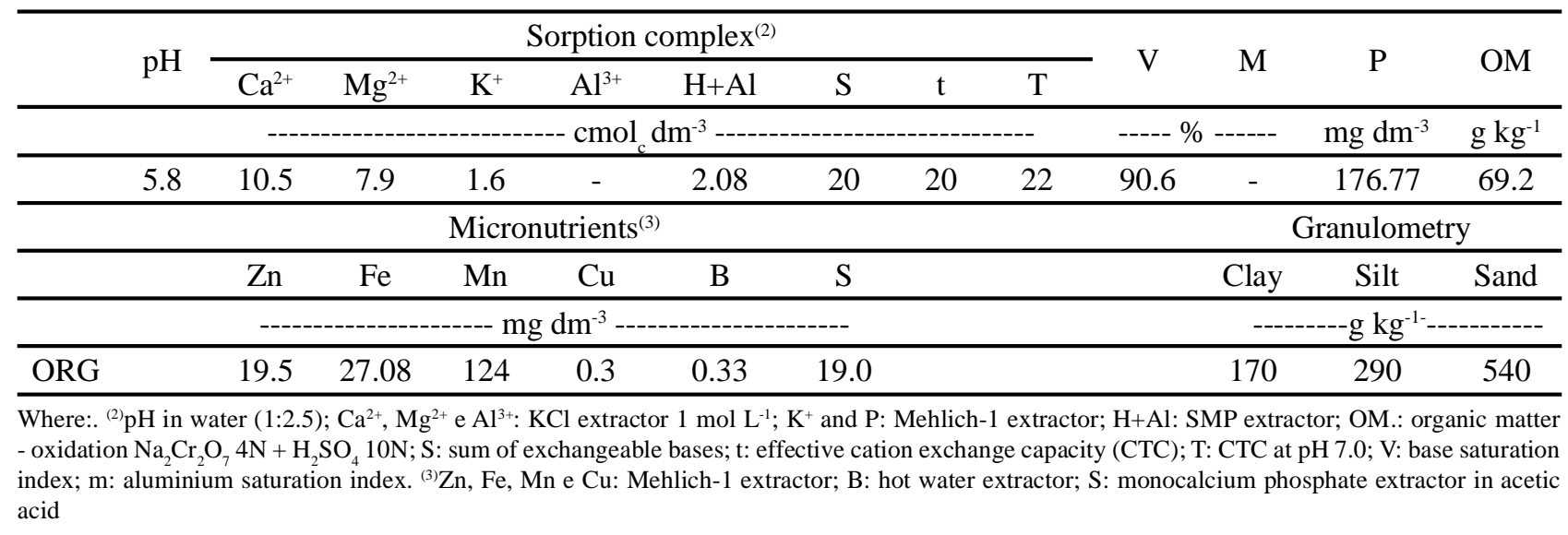

Table 2 - Composition of the nutrient solution used in the production of seedlings of Khaya ivorensis and Khaya senegalensis

\begin{tabular}{|c|c|c|c|c|c|c|c|c|c|c|c|}
\hline Composition & $\mathrm{N}-\mathrm{NO}_{3-}$ & $\mathrm{N}-\mathrm{NH}^{4+}$ & $\mathrm{P}$ & $\mathrm{K}$ & $\mathrm{Ca}$ & $\mathrm{Mg}$ & $\mathrm{S}$ & $\mathrm{Fe}$ & $\mathrm{EC}$ & [Ions] & Ionic strength \\
\hline & \multicolumn{6}{|c|}{$\mathrm{mg} \mathrm{L}^{-1}$} & \multicolumn{3}{|r|}{${\text { Ds } m^{-1}}$} & \multicolumn{2}{|c|}{$\mathrm{mmol} \mathrm{L}^{-1}$} \\
\hline Nutrient Solution & 174.0 & 24.0 & 39.0 & 183.0 & 142.0 & 38.0 & 52.0 & 32.0 & 1.74 & 26.92 & 21.94 \\
\hline
\end{tabular}


values were carried out by Tukey's test at $5 \%$ probability using the Sisvar software (FERREIRA, 2011).

\section{RESULTS AND DISCUSSION}

At the end of the experiment (140 days after transplanting) the survival rate of the Khaya ivorensis and Khaya senegalensis plants was $100 \%$ for all treatments. Each variable under analysis displayed an interaction $(\mathrm{p} \leq 0.05)$ between species and the absence or presence of nutrient solution (Table 2), showing that studying the interaction of factors is important in defining the best species-mineral fertilisation conditions for stimulating plant growth.

At 140 days after transplanting (DAT), the plants of Khaya senegalensis with added nutrient solution showed a greater mean height, corresponding to $91.0 \mathrm{~cm}$ (Table 3). The plants of Khaya senegalensis with added nutrient solution had a diameter $52.63 \%$ greater than those of Khaya ivorensis with the addition of nutrient solution (Table 3), showing the importance of the need for specific studies between each species of the genus Khaya, that would make it possible to determine the greatest diameter for each species and result in superior growth and efficiency in the use of mineral fertiliser in plants of African mahogany.

In the area of forestry seedling production, it is important that the plants show rapid growth, both in height and stem diameter, making it possible to reach quickly the ideal stage for grafting - a desired aspect of the current system of seedling production of forest species.

The mean stem diameter of the plants ranged from 8.0 to $17.9 \mathrm{~mm}$ (Table 3 ). The lowest mean value for plant stem diameter was obtained in Khaya ivorensis without the addition of nutrient solution. The superior performance of the variables of height and stem diameter in African mahogany seedlings produced in a protected environment was also noted by Smiderle et al. (2016), who concluded that cultivation in a nursery under $50 \%$ luminosity with the application of nutrient solution results in a significant increase in the values of the morphological variables.

Regarding the production of shoot dry weight, root dry weight and total dry weight, a significant difference was seen with and without the addition of nutrient solution between the species of the present study. However, the plants grown with added nutrient solution obtained higher values for dry matter production. These results agree with those found by Smiderle et al. (2017), evaluating the effects of the nutrient solution proposed by Souza et al. (2011) on seedling growth in Pochota fendleri, where, as nutrient solution was added, dry matter production in the plant increased.
This increase in dry matter production is a result (over 90\%) of the photosynthetic assimilation of carbon (SOUZA et al., 2011), which is related to the supply of nutrients, among them nitrogen $(\mathrm{N})$, in the nutrient solution formulation used in this study.

The use of nutrient solution ensures the availability and efficient use of $\mathrm{N}$ by the plants; $\mathrm{N}$ is an essential element for the components of the photosynthetic system, such as chlorophylls, and the carboxylase/ oxygenase activity of ribulose 1.5 bisphosphate and phosphoenolpyruvate carboxylase, thereby maintaining satisfactory rates of carbon assimilation (SOUZA et al., 2015), and guaranteeing the production of photoassimilates that support plant growth ( MILOŠEVIC; MILOŠEVIC; GLISIC, 2013).

However, despite being a nutrient that is only required in small amounts, adequate levels of the nutrient are essential for maintaining plant metabolism, for example, the formation and integrity of cell membranes and the production and transfer of cellular energy involving ATP, as well as in the metabolism of carbohydrates (MENEGATTI; SOUZA; BIANCHI, 2019).

Smiderle et al. (2016) and Souza et al. (2018), evaluating the effect of nutrient solution on seedling production in Khaya ivorensis and Pochota fendleri, concluded that the addition of nutrient solution gave an increase in shoot dry matter, root dry matter and total dry matter, emphasising the importance of mineral nutrition in maintaining the photosynthetic process, and consequently, in the total dry matter production of the plants, so as to achieve greater growth.

The relationship between shoot height and stem diameter (Table 3) revealed balanced growth in the plants when grown in the greenhouse. The ratio between height and diameter (HDR) is one of the most-used parameters to evaluate plant quality, since not only does it reflect the accumulation of reserves, it also ensures the greater resistance of the seedlings and a satisfactory potential for their becoming established in the field (SMIDERLE; SOUZA, 2016; SOUZA et al., 2013). This reliance on the index is due to two parameters being considered in only one indicator, allowing the value to be used as a guide to determine plant quality.

There were significant differences between treatments for macro- and micronutrient content, which was higher for both shoots and roots in the plants of Khaya senegalensis with added nutrient solution (Table 4); this is consistent with the greater gain in shoot and root dry weight of the plants (Table 3). On the whole, there was no significant difference for seedling quality (DQI) between the species of African mahogany or the addition of nutrient solution (Table 4). 
According to Souza et al. (2018), not only the HDR, but also the DQI is a good indicator of plant quality, as its calculation considers robustness and the balance of biomass distribution in the plants, including several parameters considered important; the higher its value, the better the standard of quality of the seedling.

Table 3- Height (H, cm), diameter (D, mm), shoot dry weight (SDW, g), root dry weight (RDW, g), height to diameter ratio (H/D), total dry weight (TDW, g) and Dickson quality index (DQI), determined in Khaya ivorensis and Khaya senegalensis at 140 days with and without the addition of nutrient solution

\begin{tabular}{|c|c|c|c|c|c|c|c|c|}
\hline \multirow{2}{*}{ Species } & \multicolumn{2}{|c|}{$\mathrm{H}$} & \multicolumn{2}{|c|}{$\mathrm{D}$} & \multicolumn{2}{|c|}{ SDW } & \multicolumn{2}{|c|}{ RDW } \\
\hline & WS $* * *$ & NS*** & WS & NS & WS & NS & WS & NS \\
\hline $\mathrm{T} 1 * *$ & $47.9 \mathrm{bB} *$ & $67.7 \mathrm{bA}$ & $11.3 \mathrm{bA}$ & $8.07 \mathrm{bB}$ & $25.9 \mathrm{bA}$ & $18.8 \mathrm{bB}$ & $7.8 \mathrm{bA}$ & $5.3 \mathrm{bB}$ \\
\hline $\mathrm{T} 2 * *$ & $91.0 \mathrm{aA}$ & $74.2 \mathrm{aB}$ & $17.9 \mathrm{aA}$ & $13.3 \mathrm{aB}$ & $52.3 \mathrm{aA}$ & $27.8 \mathrm{aB}$ & $12.4 \mathrm{aA}$ & $5.8 \mathrm{aB}$ \\
\hline \multirow[t]{3}{*}{ CV\% } & 7.8 & 4.7 & 5.4 & 10.1 & & & & \\
\hline & \multicolumn{2}{|c|}{$\mathrm{H} / \mathrm{D}$} & \multicolumn{2}{|c|}{ TDW } & \multicolumn{2}{|c|}{ DQI } & & \\
\hline & WS & NS & WS & NS & WS & NS & & \\
\hline $\mathrm{T} 1$ & $5.9 \mathrm{bA}$ & $5.4 \mathrm{bA}$ & $33.7 \mathrm{aA}$ & $24.1 \mathrm{aB}$ & $5.4 \mathrm{aA}$ & $3.8 \mathrm{aB}$ & & \\
\hline $\mathrm{T} 2$ & $5.5 \mathrm{aA}$ & $5.3 \mathrm{aA}$ & $33.6 \mathrm{aA}$ & $5.5 \mathrm{bB}$ & $6.8 \mathrm{aA}$ & $3.3 \mathrm{aB}$ & & \\
\hline CV\% & 0.9 & 13.7 & 5.6 & & & & & \\
\hline
\end{tabular}

*Mean values followed by the same lowercase letter in a column and uppercase letter on a line do not differ by *Tukey's test (p $\leq 0.05)$. **T1: Khaya ivorensis - T2: Khaya senegalensis; ***WS: with nutrient solution; NS: no nutritional solution

Table 4 - Mean values for macronutrient accumulation $\left(\mathrm{mg} \mathrm{plant}^{-1}\right)$ in the shoots and root system, determined in Khaya ivorensis and Khaya senegalensis at 140 days with and without nutrient solution

\begin{tabular}{|c|c|c|c|c|c|c|}
\hline \multirow[b]{3}{*}{ Species } & \multicolumn{6}{|c|}{ Shoots } \\
\hline & \multicolumn{2}{|c|}{$\mathrm{N}$} & \multicolumn{2}{|c|}{$\mathrm{P}$} & \multicolumn{2}{|c|}{$\mathrm{K}$} \\
\hline & $\mathrm{WS} * * *$ & $\mathrm{NS} * * *$ & WS & NS & WS & NS \\
\hline $\mathrm{T} 1 * *$ & $54.5 \mathrm{bA}^{*}$ & $40.9 \mathrm{bB}$ & $6.6 \mathrm{bA}$ & $5.54 \mathrm{bA}$ & $35.4 \mathrm{bA}$ & $31.47 \mathrm{bA}$ \\
\hline $\mathrm{T} 2 * *$ & $94.7 \mathrm{aA}$ & $55.2 \mathrm{aB}$ & $15.5 \mathrm{aA}$ & $10.0 \mathrm{aB}$ & $74.8 \mathrm{aA}$ & $43.2 \mathrm{aB}$ \\
\hline \multirow[t]{2}{*}{$\mathrm{CV} \%$} & \multicolumn{2}{|c|}{9.88} & \multicolumn{2}{|c|}{11.22} & \multicolumn{2}{|c|}{17.62} \\
\hline & \multicolumn{2}{|c|}{$\mathrm{Ca}$} & \multicolumn{2}{|c|}{$\mathrm{Mg}$} & \multicolumn{2}{|c|}{$\mathrm{S}$} \\
\hline $\mathrm{T} 1$ & $35.05 \mathrm{aA}$ & $21.26 \mathrm{aB}$ & $6.3 \mathrm{aA}$ & $6.2 \mathrm{aA}$ & $4.3 \mathrm{aA}$ & $2.3 \mathrm{aA}$ \\
\hline $\mathrm{T} 2$ & $38.7 \mathrm{aA}$ & $18.26 \mathrm{aB}$ & $8.6 \mathrm{aA}$ & $5.2 \mathrm{aB}$ & $7.5 \mathrm{aA}$ & $2.6 \mathrm{aB}$ \\
\hline \multirow[t]{3}{*}{ CV\% } & \multicolumn{2}{|c|}{12.01} & \multicolumn{2}{|c|}{14.95} & \multicolumn{2}{|c|}{9.76} \\
\hline & \multicolumn{6}{|c|}{ Root system } \\
\hline & \multicolumn{2}{|c|}{$\mathrm{N}$} & \multicolumn{2}{|c|}{$\mathrm{P}$} & \multicolumn{2}{|c|}{$\mathrm{K}$} \\
\hline Species & WS & NS & WS & NS & WS & NS \\
\hline $\mathrm{T} 1$ & $7.54 \mathrm{bA}$ & $6.00 \mathrm{aA}$ & $2.01 \mathrm{bA}$ & $1.02 \mathrm{aA}$ & $8.64 \mathrm{aA}$ & $9.18 \mathrm{aA}$ \\
\hline $\mathrm{T} 2$ & $12.12 \mathrm{aA}$ & $6.79 \mathrm{aB}$ & $7.42 \mathrm{aA}$ & $2.38 \mathrm{aB}$ & $13.61 \mathrm{aA}$ & $7.69 \mathrm{aB}$ \\
\hline \multirow[t]{2}{*}{$\mathrm{CV} \%$} & \multicolumn{2}{|c|}{7.66} & \multicolumn{2}{|c|}{13.2} & \multicolumn{2}{|c|}{9.7} \\
\hline & \multicolumn{2}{|c|}{$\mathrm{Ca}$} & \multicolumn{2}{|c|}{$\mathrm{Mg}$} & \multicolumn{2}{|c|}{$S$} \\
\hline $\mathrm{T} 1$ & $2.99 \mathrm{bA}$ & $2.486 \mathrm{aA}$ & $1.36 \mathrm{aA}$ & $0.91 \mathrm{aA}$ & $0.58 \mathrm{aA}$ & $0.69 \mathrm{aA}$ \\
\hline $\mathrm{T} 2$ & $12.37 \mathrm{aA}$ & $3.52 \mathrm{aB}$ & $3.92 \mathrm{aA}$ & $1.19 \mathrm{aB}$ & $0.74 \mathrm{aA}$ & $0.36 \mathrm{aA}$ \\
\hline $\mathrm{CV} \%$ & \multicolumn{2}{|c|}{13.2} & \multicolumn{2}{|c|}{7.6} & \multicolumn{2}{|c|}{4.5} \\
\hline
\end{tabular}

*Mean values followed by the same lowercase letter in a column and uppercase letter on a line do not differ by Tukey's test (p $\leq 0.05)$. **T1: Khaya ivorensis - T2: Khaya senegalensis; ***WS: with nutrient solution; NS: no nutritional solution 
In general, the lowest levels of macronutrients were seen in Khaya ivorensis when compared to Khaya senegalensis, irrespective of the addition of nutrient solution (Table 4). Even the plants of Khaya ivorensis with no nutrient solution showed low levels of the nutrients Nitrogen $(\mathrm{N})$, Potassium $(\mathrm{K})$ and Phosphorus $(\mathrm{P})$ in the shoots, with no visual symptoms of foliar deficiency. Hidden hunger may have been present in this treatment, characterised as plants being deficient in a certain nutrient but presenting no visible symptoms, the deficiency being quite detrimental to plant growth (MERIÑOGERGICHEVICH et al., 2017). This was demonstrated by the smaller stem diameter of the plants of Khaya ivorensis when compared to plants that received the added nutrient solution (Table 3).

According Menegatti, Souza and Bianchi (2019), there is a close relationship between the use of $\mathrm{K}$, i.e. between plant growth and the total content of this nutrient in the tissues, due to the need for adequate amounts of $\mathrm{K}$ in the cytoplasm to maintain several processes that involve nitrogen metabolism.

Potassium influences the metabolic processes associated with the incorporation of mineral nitrogen in the form of nitrate, either through activation of the nitrate reductase enzyme, or by signalling for the transcription and expression of genes related to the nitrate transporters responsible for $\mathrm{N}$ uptake (FALQUETO et al., 2017).

Regardless of the treatment, it was found that $\mathrm{N}$ and $\mathrm{K}$ are the most-required nutrients during the initial phase of plant growth and development in the two species of African mahogany (Table 4).

According to Smiderle et al. (2016), the ideal range for the total $\mathrm{N}$ content of African mahogany seedlings varies from 6.04 to $17.24\left(\mathrm{mg} \mathrm{plant}^{-1}\right)$, which agrees with the present research. Forest species of the genus Khaya, such as Khaya senegalensis, accumulate $(\mathrm{N})$ in the form of free proteins or amino acids, as well as non-structural carbohydrates including starch and soluble sugars (sucrose, glucose, fructose and sorbitol). Such molecules play an essential role in vegetative growth, supplying structural components for the formation of new cells and, consequently, the maximum production of biomass (HAIDER et al., 2018).

Both species of African mahogany presented values for total phosphorus content $(\mathrm{P})$ within the range $(\mathrm{P}=$ 49.53 to $69.61 \mathrm{mg} \mathrm{plant}^{-1}$ ) considered suitable for the crop (SMIDERLE et al., 2016). Adequate levels of the nutrient $\mathrm{P}$ are essential for plant metabolism, allowing rapid and intense root growth (SOUZA et al., 2019), especially due to its low mobility and its functional importance, where it participates in the formation and integrity of cell membranes throughout the production and transfer process of cellular energy involving ATP, as well as in carbohydrate metabolism (BUCHANAN et al., 2000).

The greater efficiency in the use of $\mathrm{P}$ displayed by African mahogany may be related to the smaller phosphorus requirement of these two genotypes for biochemical reactions, as well as to greater efficiency in redistributing and mobilising nutrient stored in the vacuoles to the growing points as needed (MENEGATTI; SOUZA; BIANCHI, 2019). According to Ullah et al. (2017), genotypes which are efficient in transporting $\mathrm{P}$ to the shoots guarantee a supply of the nutrient to the photosynthetically active sites in the plant, maintaining energy production for carbon metabolism, and indirectly favouring greater biomass production, a behaviour displayed by the two genotypes in question.

Regarding root-system quality in Khaya ivorensis and Khaya senegalensis with no nutrient solution added to the substrate, the roots were more fragile, breaking easily when the substrate was removed for the analysis of macro- and micronutrients. This can be attributed to calcium $(\mathrm{Ca})$, found in insufficient levels in plants of African mahogany and affecting the quality and development of new roots (HIGUCHI; HARA, 2017). However, such a deficiency may represent a serious restriction on root development, since this nutrient has limited internal redistribution due to its low mobility (SOUZA et al., 2019).

$\mathrm{Ca}$ was the third most-accumulated nutrient in the plants of Khaya ivorensis and Khaya senegalensis when added to the nutrient solution, with a maximum content of $38.74 \mathrm{mg}$ plant ${ }^{-1}$ in the shoots and $12.37 \mathrm{mg} \mathrm{plant}^{-1}$ in the roots (Table 5). At 140 DAT, the accumulated Ca content in the plants of Khaya senegalensis with added nutrient solution was greater than in the other treatments. It can be said that the greater accumulation of each nutrient is due to the higher concentration of nutrients in the nutrient solution in relation to the substrate, as well as to the high uptake of $\mathrm{Ca}$ by the crop. $\mathrm{Ca}$ is strongly related to membrane and cell-wall integrity and to root growth (SOUZA et al., 2019).

While $\mathrm{Mg}$ can be easily translocated via the phloem, $\mathrm{Ca}$ is an element with low mobility in the plant (MENEGATTI et al., 2019). It can be seen that the Mg content of the shoots of the Khaya ivorensis and Khaya senegalensis plants was within the ideal range of 5.0 to $9.0 \mathrm{mg} \mathrm{plant}^{-1}$ (SMIDERLE et al., 2016).

According to Rigon et al. (2012), adequate levels of $\mathrm{Mg}$ contribute to obtaining high photosynthetic rates and consequently better plant adaptation during the planting phase in the field. There are few studies in the domestic literature on the supply of sulphur (S) to plants of African mahogany (SMIDERLE et al., 2016). 
Table 5 - Mean values for micronutrient accumulation $\left(\mu \mathrm{g} \cdot\right.$ plant $\left.^{-1}\right)$ in the shoots and root system, determined in Khaya ivorensis and Khaya senegalensis at 140 days after transplanting

\begin{tabular}{|c|c|c|c|c|c|c|}
\hline \multirow[b]{3}{*}{ Species } & \multicolumn{6}{|c|}{ Shoots } \\
\hline & \multicolumn{2}{|c|}{ B } & \multicolumn{2}{|c|}{$\mathrm{Cu}$} & \multicolumn{2}{|c|}{$\mathrm{Fe}$} \\
\hline & WS*** & NS & WS & NS & WS & NS \\
\hline $\mathrm{T} 1 * *$ & $134.8 \mathrm{bA}^{*}$ & $52.9 \mathrm{bA}$ & $57.1 \mathrm{aA}$ & $32.4 \mathrm{bB}$ & $407.8 \mathrm{bA}$ & $194.9 \mathrm{bB}$ \\
\hline $\mathrm{T} 2$ & $288.0 \mathrm{aA}$ & $63.9 \mathrm{aB}$ & $72.7 \mathrm{bA}$ & $51.0 \mathrm{aB}$ & $682.1 \mathrm{aA}$ & $287.0 \mathrm{aB}$ \\
\hline \multirow[t]{2}{*}{ CV\% } & \multicolumn{2}{|c|}{15.5} & \multicolumn{2}{|c|}{10.8} & \multicolumn{2}{|c|}{9.3} \\
\hline & \multicolumn{2}{|c|}{$\mathrm{Mn}$} & \multicolumn{2}{|c|}{$\mathrm{Zn}$} & & \\
\hline $\mathrm{T} 1$ & $75.6 \mathrm{bA}$ & $45.6 \mathrm{bB}$ & $41.0 \mathrm{bA}$ & $22.5 \mathrm{bB}$ & & \\
\hline $\mathrm{T} 2$ & $107.0 \mathrm{aA}$ & $65.9 \mathrm{aB}$ & $69.3 \mathrm{aA}$ & $37.9 \mathrm{aB}$ & & \\
\hline \multirow[t]{3}{*}{$\mathrm{CV} \%$} & \multicolumn{2}{|c|}{10.5} & \multicolumn{2}{|c|}{9.8} & & \\
\hline & \multicolumn{6}{|c|}{ Root system } \\
\hline & \multicolumn{2}{|c|}{ B } & \multicolumn{2}{|c|}{$\mathrm{Cu}$} & \multicolumn{2}{|c|}{$\mathrm{Fe}$} \\
\hline Species & WS & NS & WS & NS & WS & NS \\
\hline $\mathrm{T} 1 * *$ & $73.2 \mathrm{bA}$ & $42.3 \mathrm{bB}$ & $58.6 \mathrm{bA}$ & $33.4 \mathrm{bB}$ & $135.3 \mathrm{bA}$ & $53.9 \mathrm{bB}$ \\
\hline $\mathrm{T} 2$ & $96.8 \mathrm{aA}$ & $62.9 \mathrm{aB}$ & $73.2 \mathrm{aA}$ & $55.4 \mathrm{aB}$ & $190.6 \mathrm{aA}$ & $89.2 \mathrm{aB}$ \\
\hline \multirow[t]{2}{*}{$\mathrm{CV} \%$} & \multicolumn{2}{|c|}{10.8} & \multicolumn{2}{|c|}{12.3} & \multicolumn{2}{|c|}{13.9} \\
\hline & \multicolumn{2}{|c|}{$\mathrm{Mn}$} & \multicolumn{2}{|c|}{$\mathrm{Zn}$} & & \\
\hline $\mathrm{T} 1$ & $41.9 \mathrm{bA}$ & $25.3 \mathrm{bB}$ & $61.1 \mathrm{aA}$ & $46.9 \mathrm{aB}$ & & \\
\hline $\mathrm{T} 2$ & $68.7 \mathrm{aA}$ & $36.3 \mathrm{aB}$ & $39.3 \mathrm{bA}$ & $24.9 \mathrm{bB}$ & & \\
\hline $\mathrm{CV} \%$ & 9.1 & 10.8 & & & & \\
\hline
\end{tabular}

*Mean values followed by the same lowercase letter in a column and uppercase letter on a line, do not differ by Tukey's test (p $\leq 0.05$ ). **T1: Khaya ivorensis - T2: Khaya senegalensis; ***WS: with nutrient solution; NS: no nutritional solution

It was found that the $\mathrm{S}$ content of the shoots varied from 2.28 to $7.57 \mathrm{mg}$ plant $^{-1}$. According to Raij (1991), a suitable $\mathrm{S}$ content for the shoots of forest species is generally between 3.0 and $8.90 \mathrm{mg}$ plant $^{-1}$. In the present study, the $\mathrm{S}$ content was within the range established by Raij (1991), except in the control treatment for both species (Table 5). Sulphur applied in suitable doses can favour better plant growth and development due to participating in the conversion of non-protein to protein nitrogen (SOUZA et al., 2019).

Smiderle et al. (2017) demonstrated that Iron (Fe) is the micronutrient that is most accumulated by plants during the initial growth stage, followed by manganese (Mn). However, under the conditions of the present research, the mean $\mathrm{Fe}$ content was within the ideal range (682.1 to $194.9 \mu \mathrm{g}$ plant $^{-1}$ ) for the species of African mahogany as reported by Alves et al. (2016), except for plants that received no added nutrient solution (control), where it was below the ideal range (Table 5). It is known that $\mathrm{Fe}$ plays an important role in enzyme activation, acting as a prosthetic group (JUCOSKI et al., 2016). In addition, it catalyses chlorophyll biosynthesis, since it comprises part of the enzymes responsible for chlorophyll formation (SOUZA et al., 2019).

In turn, the treatments that received nutrient solution showed a Copper $(\mathrm{Cu})$ and $\mathrm{Mn}$ content within the appropriate range, while the other treatments did not provide adequate levels of $\mathrm{Cu}$ for Khaya ivorensis or Khaya senegalensis, according to Alves et al. (2016) and Smiderle et al. (2016) respectively.

The highest levels of zinc ( $\mathrm{Zn}$ ) were detected in the shoots of both Khaya ivorensis and Khaya senegalensis, accounting for over $50 \%$ of the total accumulated in the plants with added nutrient solution (Table 5).

Different responses for nutrient uptake efficiency were seen in plants with and without the addition of nutrient solution relative to the species of African mahogany (Table 6), with maximum values for macronutrient uptake efficiency recorded in plants of $K$. senegalensis with the application of nutrient solution (Table 6).

According to Souza et al. (2019), transport efficiency indicates the ability of the plant to transport nutrients from the 
Table 6 - Efficiency in the uptake and use of macronutrients, determined in Khaya ivorensis and Khaya senegalensis at 140 days after transplanting, with and without addition of nutrient solution

\begin{tabular}{|c|c|c|c|c|c|c|}
\hline \multirow[b]{3}{*}{ Species } & \multicolumn{6}{|c|}{ Uptake efficiency } \\
\hline & \multicolumn{2}{|c|}{$\mathrm{N}$} & \multicolumn{2}{|c|}{$\mathrm{P}$} & \multicolumn{2}{|c|}{$\mathrm{K}$} \\
\hline & $\mathrm{WS} * * *$ & NS & WS & NS & WS & NS \\
\hline & \multicolumn{6}{|c|}{ mg nutrient/g root dry weight } \\
\hline $\mathrm{T} 1 * *$ & $8.2 \mathrm{bA}^{*}$ & $8.5 \mathrm{aA}$ & $2.1 \mathrm{bA}$ & $1.8 \mathrm{bA}$ & $5.1 \mathrm{bA}$ & $4.1 \mathrm{aA}$ \\
\hline $\mathrm{T} 2$ & $10.6 \mathrm{aA}$ & $7.8 \mathrm{aB}$ & $6.3 \mathrm{aA}$ & $4.3 \mathrm{aB}$ & $8.7 \mathrm{aA}$ & $7.4 \mathrm{bA}$ \\
\hline \multirow[t]{2}{*}{$* * * * \mathrm{CV} . \%$} & \multicolumn{2}{|c|}{9.6} & \multicolumn{2}{|c|}{4.7} & \multicolumn{2}{|c|}{3.9} \\
\hline & \multicolumn{2}{|c|}{$\mathrm{Ca}$} & \multicolumn{2}{|c|}{$\mathrm{Mg}$} & \multicolumn{2}{|c|}{$\mathrm{S}$} \\
\hline $\mathrm{T} 1$ & $4.1 \mathrm{bA}$ & $3.7 \mathrm{bA}$ & $1.10 \mathrm{bA}$ & $0.9 \mathrm{bA}$ & $0.6 \mathrm{bA}$ & $0.5 \mathrm{bA}$ \\
\hline $\mathrm{T} 2$ & $12.7 \mathrm{aA}$ & $9.5 \mathrm{aB}$ & $5.6 \mathrm{aA}$ & $7.7 \mathrm{aB}$ & $8.3 \mathrm{aA}$ & $4.8 \mathrm{aB}$ \\
\hline \multirow[t]{5}{*}{ CV.\% } & 8.5 & 12.9 & 7.4 & & & \\
\hline & \multicolumn{6}{|c|}{ Transport efficiency } \\
\hline & \multicolumn{6}{|c|}{ 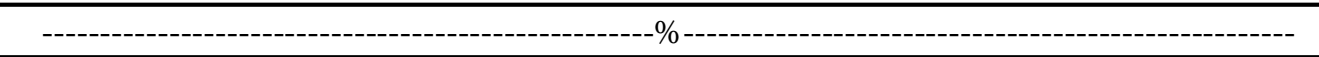 } \\
\hline & \multicolumn{2}{|c|}{$\mathrm{N}$} & \multicolumn{2}{|c|}{$\mathrm{P}$} & \multicolumn{2}{|c|}{$\mathrm{K}$} \\
\hline & WS & NS & WS & NS & WS & $\mathrm{NS}$ \\
\hline $\mathrm{T} 1$ & $89.0 \mathrm{aA}$ & $88.6 \mathrm{aA}$ & $80.7 \mathrm{bA}$ & $67.6 \mathrm{bB}$ & $80.4 \mathrm{bA}$ & $76.6 \mathrm{bB}$ \\
\hline $\mathrm{T} 2$ & $87.8 \mathrm{bA}$ & $87.2 \mathrm{aA}$ & $84.3 \mathrm{aA}$ & $76.8 \mathrm{aB}$ & $84.4 \mathrm{aA}$ & $80.3 \mathrm{aB}$ \\
\hline \multirow[t]{2}{*}{ CV.\% } & \multicolumn{2}{|c|}{10.5} & \multicolumn{2}{|c|}{12.1} & \multicolumn{2}{|c|}{13.2} \\
\hline & \multicolumn{2}{|c|}{$\mathrm{Ca}$} & \multicolumn{2}{|c|}{$\mathrm{Mg}$} & \multicolumn{2}{|c|}{$\mathrm{S}$} \\
\hline $\mathrm{T} 1$ & $83.8 \mathrm{bA}$ & $75.8 \mathrm{bB}$ & $81.3 \mathrm{bA}$ & $72.8 \mathrm{bB}$ & $91.1 \mathrm{bA}$ & $70.2 \mathrm{bB}$ \\
\hline $\mathrm{T} 2$ & $92.1 \mathrm{aA}$ & $86.5 \mathrm{aB}$ & $87.2 \mathrm{aA}$ & $82.2 \mathrm{aB}$ & $98.0 \mathrm{aA}$ & $86.3 \mathrm{aB}$ \\
\hline \multirow[t]{5}{*}{ CV.\% } & \multicolumn{2}{|c|}{9.1} & \multicolumn{2}{|c|}{10.8} & & \\
\hline & & & Use & ncy & & \\
\hline & & & eight $)^{2} \mathrm{~g} / \mathrm{n}$ & mulated r & & \\
\hline & & & & & & \\
\hline & WS & NS & WS & NS & WS & $\mathrm{NS}$ \\
\hline $\mathrm{T} 1$ & $0.2 \mathrm{bA}$ & $0.2 \mathrm{bA}$ & $1.4 \mathrm{bA}$ & $0.7 \mathrm{bB}$ & $0.3 \mathrm{bA}$ & $0.2 \mathrm{bA}$ \\
\hline $\mathrm{T} 2$ & $1.1 \mathrm{aA}$ & $1.1 \mathrm{aA}$ & $7.9 \mathrm{aA}$ & $6.1 \mathrm{aB}$ & $1.5 \mathrm{aA}$ & $1.2 \mathrm{aA}$ \\
\hline $\mathrm{CV} \%$ & & & & & & \\
\hline & & & & & & \\
\hline $\mathrm{T} 1$ & $0.7 \mathrm{bA}$ & $0.5 \mathrm{bA}$ & $2.1 \mathrm{bA}$ & $1.4 \mathrm{bA}$ & $4.6 \mathrm{bA}$ & $2.1 \mathrm{bB}$ \\
\hline $\mathrm{T} 2$ & $2.7 \mathrm{aA}$ & $1.2 \mathrm{aB}$ & $8.7 \mathrm{aA}$ & $5.7 \mathrm{aB}$ & $16.8 \mathrm{aA}$ & $10.7 \mathrm{aB}$ \\
\hline $\mathrm{CV} \%$ & & & & & & \\
\hline
\end{tabular}

*Mean values followed by the same lowercase letter in a column and uppercase letter on a line, do not differ by Tukey's test (p $\leq 0.05)$. **T1: Khaya ivorensis - T2: Khaya senegalensis; ***WS: with nutrient solution; NS: no nutritional solution; ****CV $(\%)=$ coefficient of variation as a percentage

roots to the shoots and to incorporate the absorbed nutrient into biomass. Under the conditions of the present study, the plants of Khaya senegalensis that received added nutrient solution best fit the genetic potential of the African mahogany plants, showing a significant difference to the plants of both Khaya senegalensis and Khaya ivorensis that did not receive nutrient solution, with the exception of nitrogen.
There are no studies of the nutrient-use efficiency of plants of both Khaya ivorensis and Khaya senegalensis via nutrient solution and substrate. In general, the plants of Khaya ivorensis with the addition of nutrient solution proved to be more efficient in using $\mathrm{Mg}$ and $\mathrm{S}$ (Table 6). A higher nitrate content contributes to the dynamics of the cationic nutrients in the soil, since the $\mathrm{NO}^{3-}$ anion is 
considered an accompanying ion of $\mathrm{Ca}^{2+}, \mathrm{Mg}^{2+}, \mathrm{K}^{+}$and $\mathrm{Al}^{3+}$ (SOUZA et al., 2018) and may therefore improve the uptake and use of these nutrients, with the results being seen in the morphometric characteristics of the plants, e.g. the greater investment in shoot growth and stem diameter recorded in the present study.
The results of the present study also lead to the conclusion that there was a significant difference in micronutrient-use efficiency in Khaya ivorensis both with and without the added nutrient solution, except for Boron (Table 7). This confirms the effect of such micronutrients as $\mathrm{Cu}, \mathrm{Mn}$ and $\mathrm{Fe}$ in electron transport

Table 7 - Uptake efficiency, nutrient transport efficiency and micronutrient-use efficiency, determined in Khaya ivorensis and Khaya senegalensis at 140 days after transplanting, with and without nutrient solution

\begin{tabular}{|c|c|c|c|c|c|c|}
\hline \multirow[b]{4}{*}{ Species } & \multicolumn{6}{|c|}{ Uptake efficiency* } \\
\hline & \multicolumn{6}{|c|}{$\mathrm{mg}$ nutrient/g root dry weight } \\
\hline & \multicolumn{2}{|c|}{$\mathrm{B}$} & \multicolumn{2}{|c|}{$\mathrm{Cu}$} & \multicolumn{2}{|c|}{$\mathrm{Fe}$} \\
\hline & $\mathrm{WS} * * *$ & NS & WS & NS & WS & NS \\
\hline $\mathrm{T} 1 * *$ & $2.86 \mathrm{bA}$ & $2.25 \mathrm{bA}$ & $1.97 \mathrm{bA}$ & $1.97 \mathrm{bA}$ & $2.80 \mathrm{bA}$ & $2.80 \mathrm{bA}$ \\
\hline $\mathrm{T} 2$ & $28.14 \mathrm{aA}$ & $27.65 \mathrm{aA}$ & $21.3 \mathrm{aA}$ & $10.2 \mathrm{aB}$ & $17.59 \mathrm{aA}$ & $14.11 \mathrm{aB}$ \\
\hline \multirow[t]{2}{*}{$* * * * \mathrm{CV} . \%$} & \multicolumn{2}{|c|}{8.9} & \multicolumn{2}{|c|}{7.7} & \multicolumn{2}{|c|}{10.9} \\
\hline & \multicolumn{2}{|c|}{$\mathrm{Mn}$} & \multicolumn{2}{|c|}{$\mathrm{Zn}$} & & \\
\hline $\mathrm{T} 1$ & $1.67 \mathrm{bA}$ & $1.48 \mathrm{bA}$ & $4.62 \mathrm{bA}$ & $4.01 \mathrm{bA}$ & & \\
\hline $\mathrm{T} 2$ & $10.80 \mathrm{aA}$ & $8.71 \mathrm{aB}$ & $57.8 \mathrm{aA}$ & $53.6 \mathrm{aB}$ & & \\
\hline \multirow[t]{5}{*}{ CV.\% } & \multicolumn{2}{|c|}{9.3} & \multicolumn{2}{|c|}{13.8} & & \\
\hline & \multicolumn{6}{|c|}{ Transport efficiency** } \\
\hline & \multicolumn{6}{|c|}{ 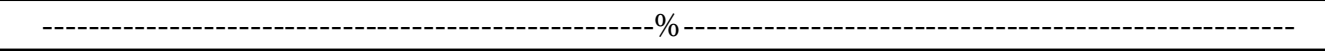 } \\
\hline & $\mathrm{B}$ & $\mathrm{Cu}$ & $\mathrm{Fe}$ & & & \\
\hline & WS & NS & WS & NS & WS & NS \\
\hline $\mathrm{T} 1 * *$ & $65.09 \mathrm{bA}$ & $55.57 \mathrm{bB}$ & $49.3 \mathrm{bA}$ & $49.2 \mathrm{bA}$ & $64.3 \mathrm{bA}$ & $64.3 \mathrm{bA}$ \\
\hline $\mathrm{T} 2$ & $82.07 \mathrm{aA}$ & $39.70 \mathrm{aB}$ & $56.6 \mathrm{aA}$ & $41.0 \mathrm{aB}$ & $64.4 \mathrm{aA}$ & $60.8 \mathrm{aB}$ \\
\hline \multirow[t]{2}{*}{ CV.\% } & \multicolumn{2}{|c|}{14.1} & \multicolumn{2}{|c|}{13.8} & \multicolumn{2}{|c|}{13.7} \\
\hline & \multicolumn{2}{|c|}{$\mathrm{Mn}$} & \multicolumn{2}{|c|}{$\mathrm{Zn}$} & & \\
\hline $\mathrm{T} 1$ & $40.2 \mathrm{bA}$ & $32.5 \mathrm{bB}$ & $78.4 \mathrm{bA}$ & $67.0 \mathrm{bB}$ & & \\
\hline $\mathrm{T} 2$ & $63.8 \mathrm{aA}$ & $60.3 \mathrm{aB}$ & $94.5 \mathrm{aA}$ & $92.1 \mathrm{aB}$ & & \\
\hline \multirow[t]{5}{*}{ CV.\% } & \multicolumn{2}{|c|}{14.1} & \multicolumn{2}{|c|}{13.8} & & \\
\hline & \multicolumn{6}{|c|}{ Use efficiency*** } \\
\hline & \multicolumn{6}{|c|}{$(\text { dry weight })^{2} \mathrm{~g} / \mathrm{mg}$ accumulated nutrient } \\
\hline & \multicolumn{2}{|c|}{$\mathrm{B}$} & & & & \\
\hline & WS & NS & WS & NS & WS & NS \\
\hline $\mathrm{T} 1$ & $0.07 \mathrm{bA}$ & $0.06 \mathrm{bA}$ & $0.19 \mathrm{bA}$ & $0.08 \mathrm{bB}$ & $0.14 \mathrm{bA}$ & $0.10 \mathrm{bB}$ \\
\hline $\mathrm{T} 2$ & $0.53 \mathrm{aA}$ & $0.31 \mathrm{aB}$ & $0.78 \mathrm{aA}$ & $0.53 \mathrm{aB}$ & $0.68 \mathrm{aA}$ & $0.53 \mathrm{aB}$ \\
\hline CV.\% & & & & & & \\
\hline & & & & & & \\
\hline $\mathrm{T} 1$ & & & & & & \\
\hline $\mathrm{T} 2$ & & & & & & \\
\hline CV.\% & & & & & & \\
\hline
\end{tabular}

* Mean values followed by the same lowercase letter in a column and uppercase letter on a line, do not differ by Tukey's test (p $\leq 0.05$ ). **T1: Khaya ivorensis - T2: Khaya senegalensis; ***WS: with nutrient solution; NS: no nutritient solution; ****CV $(\%)=$ coefficient of variation as a percentage 
during photosynthesis, on the greater growth of the African mahogany plants.

Considering the results obtained in this study, it is suggested that the adequate use of nutrients allows greater efficiency in the use of production resources, and if used together with the addition of nutrient solution to the substrate, it is possible to achieve the early production of African mahogany seedlings with a high standard of quality.

There is no information on the mechanisms of uptake, translocation, remobilisation or nutrient-use efficiency in plants of Khaya senegalensis or Khaya ivorensis in either the domestic or international literature. The present study makes an important contribution, with information for guiding the nutritional management of plants of African mahogany during the production phase of the seedlings.

\section{CONCLUSION}

1. Maintaining the plants of Khaya senegalensis and Khaya ivorensis with the addition of nutrient solution provides conditions for nutrient use, and allows plants with excellent morphological and nutritional characteristics to be ready for the field within five months after transplanting in a shaded nursery;

2. The most efficient uptake, transport and use of macroand micronutrients is found in the species Khaya senegalensis with the addition of nutrient solution.

\section{ACKNOWLEDGMENTS}

The authors wish to thank the Postgraduate Program of the Federal University of Roraima - UFRR (POSAGRO) working in partnership with EMBRAPA Roraima. We thank CNPq (National Council for Scientific and Technological Development), for the Productivity and Research scholarship to the corresponding second and third author.

\section{REFERENCES}

ALVES, M. S. et al. Crescimento e marcha de absorção de nutrientes em mudas de Khaya ivorensis. Acta Iguazu, v. 5, n. 2, p. 95-110, 2016.

BALDI, E. et al. Effect of organic fertilization on nutrient concentration and accumulation in nectarine (Prunus persica var. nucipersica) trees: The effect of rate of application. Scientia Horticulturae, v. 179, n. 1, p. 174-179, 2014.
BATAGLIA, O. C. et al. Methods of chemical analysis of plants. Campinas: Agronomic Institute, 1983. 48 p.

BUCHANAN, B. B. et al. Biochemistry \& Molecular Biology of Plants. Rockville: American Society of Plant Biologists, 2000. $1367 \mathrm{p}$.

CENTRE FOR AGRICULTURE AND BIOSCIENCES INTERNATIONAL. Forestry Compendium [online]. Wallingford: CAB International, 2013. Disponível em: www. cabi.org/fc. Acesso em: 12 maio 2019.

DICKSON, A.; LEAD, A.; OSMER, J. F. Quality appraisal of white spruce and white pine seedling stock in nurseries. Forestry Chronicle, v. 36, n. 3, p. 10-13, 1960.

ELSADR, H. T.; SHERIF, S. Peaches and nectarines. Encyclopedia of Food and Health, v. 122, n. 1, p. 270-276, 2016.

FALQUETO, A. R. et al. Effects of drought stress on chlorophyll a fluorescence in two rubber tree clones. Scientia Horticulturae, v. 224, n. 4, p. 238-243, 2017.

FERREIRA, D. F. Sisvar: a computer statistical analysis system. Ciência e Agrotecnologia, v. 35, n. 3, p. 1039-1042, 2011.

HAIDER, M. S. et al. Drought stress revealed physiological, biochemical and gene-expressional variations in 'Yoshihime' peach (Prunus Persica L.) cultivar. Journal of Plant Interactions, v. 13, n. 2, p. 83-90, 2018.

HIGUCHI, K.; HARA, K. Common reed absorbs $\mathrm{K}+$ more selectively than rice against high $\mathrm{Na}^{+} / \mathrm{K}^{+}$ratio in nutrient solution. Soil Science and Plant Nutrition, v. 3, n. 2, p. 483487, 2017.

INTERNATIONAL TROPICAL TIMBER ORGANIZATION. Annual review and assessment of the world timber situation [online]. Yokohama: ITTO, 2011. Disponível em: http://www. itto.int/annual_review/. Acesso em: 11 maio 2019.

JUCOSKI, G. O. et al. Excess iron on growth and mineral composition in Eugenia uniflora L. Revista Ciência Agronômica, v. 47, n. 4, p. 720-728, 2016.

LI, B.; MCKEAND, S. E.; ALLEN, H. L. Genetic variation in nitrogen use efficiency of loblolly pine seedlings. Forest Science, v. 37, n. 2, p. 613-626, 1991.

MALAVOLTA, E.; VITTI, G. C.; OLIVEIRA, S. A. Avaliação do estado nutricional das plantas: princípios e aplicações. 2. ed. Piracicaba: Potafos, 1997. 319 p.

MENEGATTI, R. D.; SOUZA, A. G.; BIANCHI, V. J. Growth and nutrient accumulation in three peach rootstocks until the grafting stage. Comunicata Scientiae, v. 10, n. 4, p. 1-7, 2019.

MERIÑO-GERGICHEVICH, C. et al. Physiological and nutritional responses in two highbush blueberry cultivars exposed to deficiency and excess of boron. Journal of Soil Science and Plant Nutrition, v. 17, n. 1, p. 307-318, 2017.

MILOŠEVIC, T.; MILOŠEVIC, N.; GLISIC, I. Agronomic properties and nutritional status of plum trees (Prunus domestica 
L.) influenced by different cultivars. Journal of Soil Science and Plant Nutrition, v. 13, n. 4, p. 706-714, 2013.

PRADEEPKUMAR, T. et al. Effect of organic and inorganic nutrient sources on the yield of selected tropical vegetables. Scientia Horticulturae, v. 224, n. 3, p. 84-92, 2017.

RAIJ, B. Soil fertility and fertilization. Piracicaba: Potafós, 1991. $343 \mathrm{p}$.

RIGON, J. P. G. et al. Non destructive analysis of photosynthetic pigments in leaves of Sesamum indicum (L.). Revista Brasileira de Engenharia Agrícola e Ambiental, v. 16, n. 1, p. 258-261, 2012.

SIDDIQI, M. Y.; GLASS, A. D. M. Utilization index: a modified approach to the estimation and comparison of nutrient efficiency in plants. Journal of Soil Science and Plant Nutrition, v. 4, n. 3, p. 289-302, 1981

SMIDERLE, O. J. et al. Growth and nutritional status and quality of Khaya senegalensis seedlings. Revista Ciências Agrárias, v. 59, n. 1, p. 47-53, 2016.

SMIDERLE, O. J. et al. Nutrient solution and substrates for 'cedro doce' (Pochota fendleri) seedling production. Revista Brasileira de Engenharia Agrícola e Ambiental, v. 21, n. 4, p. 227-231, 2017.

SMIDERLE, O. J.; SOUZA, A. G. Production and quality of Cinnamomum zeylanicum Blume seedlings cultivated in nutrient solution. Revista Brasileira de Ciências Agrárias, v. 2, n. 2, p. 104-110, 2016

SOMMER, J. et al. Allocation and dynamics of $\mathrm{C}$ and $\mathrm{N}$ within plant-soil system of ash and beech. Journal of Plant Nutrition and Soil Science, v. 179, n. 3, p. 376-387, 2016.
SOUZA, A. G. et al. Dry matter and nutrient accumulation in grafted peach seedlings in hydroponic system. Revista Brasileira de Fruticultura, v. 37, n. 2, p. 240-246, 2015.

SOUZA, A. G. et al. Morphophysiological quality of plantlets and grafted peach trees: effects of nutrient solution and substrates. Recent Patents on Food, Nutrition \& Agriculture, v. 1, n. 1, p. 10- 18, 2018.

SOUZA, A. G. et al. Nutritional efficiency and morphophysiological aspects with growth in the 'okinawa roxo' peach rootstock. Journal of Agricultural Science, v. 11, n. 9, p. 1-13 2019.

SOUZA, A. G. et al. Optimization of germination and initial quality of seedlings of Prunus persica tree rootstocks. Journal of Seed Science, v. 39, n. 2, p. 166-173, 2017.

SOUZA, A. G. et al. Produção de mudas tangerineira "Pokan" em sistema hidropônico. Revista Ciência Agronômica, v. 44, n. 4, p. 296-297, 2013.

SOUZA, A. G. et al. Production of peach grafts under hydroponic conditions. Ciência e Agrotecnologia, v. 35, n. 2, p. 322-326, 2011.

SWIADER, J. M.; CHYAN, Y.; FREIJI, F. G. Genotypic differences in nitrate uptake and utilization efficiency in pumpkin hybrids. Journal of Seed Science, v. 17, n. 2, p. 1687-1699, 1994.

ULLAH, S. et al. Effect of phosphorous and zinc under different application methods on yield attributes of chickpea (Cicer arietinum L.). International Journal of Agricultural and Environmental Research, v. 3, n. 2, p. 79-85, 2017. 